\title{
ANALISIS PERKEMBANGAN PRAKTIK BAITUL MAAL PADA MASA DAULAH ISLAMIYAH DAN DALAM KONTEKS DI INDONESIA
}

\author{
Risa Sari Pertiwi \\ Magister Sains Ekonomi Islam, Universitas Airlangga, Surabaya \\ Email: risa.sari.pertiwi-2018@pasca.unair.ac.id \\ Sri Herianingrum \\ Departemen Ekonomi Syariah, Universitas Airlangga, Surabaya \\ Email: sri.herianingrum@,feb.unair.ac.id \\ Ridan Muhtadi \\ STAI Miftahul Ulum, Pamekasan \\ Email: ridanmuhtadi@gmail.com
}

\section{Mumuh Muhammad}

Sosyal Bilimler Enstitusu, Islamic Economics and Finance, Istanbul University, Turkey

Email: mumuh.muhammad@ogr.iu.edu.tr

\begin{abstract}
:
Purpose of this study is to analyze the development of the Baitul Maal practice during the Daulah Islamiyab era and in the context of Indonesia. This study uses a qualitative approach was used through library research using various relevant library materials and previous literature studies. The main finding of this research is that the development of Baitul Maal during the Daulah Islamiyah period always experienced developments in terms of institutional, administrative, construction of central and local Baitul Maal sites and fiscal policy in the distribution of Baitul Maal assets. The main sources of income of Baitul Maal in the early days of Islamic development were khums, zakat, kharaj and jizyah in which the amount, duration and usage were based on the Qur'an and Hadith, while the expenditure of Baitul Maal funds during the Islamic State was focused on the public service sector. Nowadays, there are several different aspects between the Daulah Islamiyah and Indonesia which can be seen concepts, institutions, roles and functions, sources of income and types of expenditure Baitul Maal.
\end{abstract}

Keywords: Baitul Maal, Daulah Islamiyah, Islamic Public Finance 


\begin{abstract}
Abstrak
Tujuan penelitian ini untuk menganalisis perkembangan praktik Baitul Maal pada masa Daulah Islamiyah dan dalam konteks di Indonesia saat ini. Pendekatan penelitian kualitatif melalui studi pustaka (library research) dari berbagai bahan pustaka (referensi) yang relevan. Hasil penelitian menunjukkan bahwa perkembangan Baitul Maal pada masa Daulah Islamiyah selalu mengalami perkembangan dari segi kelembagaan, administrasi, pembangunan tempat Baitul Maal pusat dan lokal serta kebijakan fiskal dalam pendistribusian harta Baitul Maal. Sumber pendapatan utama Baitul Maal pada masa awal perkembangan Islam adalah khums, zakat, kharaj dan jizyah yang ketentuannya didasarkan pada ketentuan Syariah, sedangkan pengeluaran dana Baitul Maal pada masa Daulah Islamiyah fokus kepada sektor layanan publik. Analisis perkembangan eksistensi Baitul Maal pada masa Daulah Islamiyah dan di Indonesia saat ini memiliki perbedaan dari beberapa aspek antara lain konsep, kelembagaan, peran dan fungsi, sumber pendapatan serta jenis pengeluaran Baitul Maal.
\end{abstract}

Kata Kunci: Baitul Maal, Daulah Islamiyah, Keuangan Publik Islam

\title{
Pendahuluan
}

Pada Abad ketujuh, Nabi Muhammad SAW yang pada saat itu menjabat sebagai kepala negara telah memperkenalkan konsep baru dalam bidang keuangan negara pada abad ketujuh. Seluruh harta kekayaan negara harus dikumpulkan dan dikeluarkan sesuai dengan kebutuhan negara. Nama pusat pengumpulan harta negara tersebut disebut Baitul Maal yang terletak di Masjid Nabawi. ${ }^{1}$ Keberadaan Baitul Maal telah ada dari masa pemerintahan Nabi Muhammad SAW ketika kaum Muslimin memenangkan perang Badar sehingga kaum Muslimin memperoleh harta rampasan perang (ghanimah). Setelah itu, di antara para sahabat beselisih pemahaman mengenai cara pembagian ghanimah, sehingga turunlah ayat QS. Al-Anfal: 1 yang menjelaskan bahwa harta rampasan perang merupakan milik Allah SWT dan Rasul Allah serta diperintahkan untuk bertakwa kepada Allah dan memperbaiki hubungan sesama manusia, selanjutnya perintah taat kepada Allah dan RasulNya jika termasuk orang yang beriman.

${ }^{1}$ Euis, A. Sejarah Pemikiran Ekonomi Islam dari Masa Klasik bingga Kontemporer. (Depok: Gramata Publishing, 2005), 78.

Vol.6 No. 1 Juni $2020 \mid 54$ 
Baitul Maal pada masa Rasulullah SAW belum memiliki tempat untuk menyimpan harta perolehan negara, karena pada saat itu belum begitu banyak perolehan hartanya dan juga harta akan segera didistribusikan kepada rakyatnya. Adapun perkembangan Baitul Maal setelah masa Rasulullah SAW kemudian secara bertahap mulai dari Abu Bakar Ash Shiddiq dan diperluas pada masa Umar bin Khattab, Utsman dan Ali bin Abi Thalib. Ummat Islam pada saat penaklukan wilayah mulai mempelajari ilmu tata negara pemerintahan Persia, maka hal tersebut mulai diterapkan pada Baitul Maal. Selama pemerintahan Khalifah Ali, sistem administrasi Baitul Maal di tingkat pusat maupun lokal sudah berjalan baik. Hal ini terlihat dari adanya kerjasama antara pusat dan daerah, sehingga perolehan harta Baitul Maal mengalami surplus dan kelebihannya dibagikan secara proporsional. ${ }^{2}$

Pelaksana kebijakan fiskal negara Islam pada saat itu dilakukan oleh Baitul Maal. Perkembangan pengelolaan Baitul Maal kemudian dilanjutkan oleh Daulah Islamiyah, dan diakhiri pada masa kekhilafahan Islam runtuh tahun 1924 M. Baitul Maal pada masa Daulah Islamiyah merupakan lembaga atau institusi keuangan negara sebagai tempat dan pengelolaan dana umat dari pengumpulan sumber pendapatan hingga pengalokasian belanja negara sesuai dengan kaidah Islam. Adapun konteks Baitul Maal saat ini di Indonesia merupakan Lembaga Keuangan Mikro Syariah yang memiliki fungsi sosial mengumpulkan titipan dana zakat, infaq, sedekah serta mengoptimalkan pendistribusiannya sesuai dengan ketentuannya. ${ }^{3} \mathrm{Hal}$ ini akan menimbulkan perbedaan persepsi antara Baitul Maal pada masa Daulah Islamiyah dan dalam perkembangan negara saat ini.

Konsep keuangan publik Islam salah satunya mengenai konsep Baitul Maal yang tidak hanya merupakan struktur perbendaharaan tetapi juga praktis dari keseluruhan sistem fiskal negara. ${ }^{4}$ Hal ini dalam gagasan Al-Ghazali bahwa negara berperan dalam mewujudkan keadilan, stabilitas dan keamanan demi tercapainya Maqashid Syariah. ${ }^{5}$ Oleh karena itu, analisis perkembangan

\footnotetext{
2 Adiwarman, A. A. Sejarah Pemikiran Ekonomi Islam. (Jakarta: RajaGrafindo Persada, 2014), 105.

${ }^{3}$ Andri, S. Bank dan Lembaga Keuangan Syariah. (Jakarta: PrenadaMedia Grup, 2018), 473.

${ }^{4}$ S. M. Hasanuz Zaman. Economics Functions of an Islamic State The Early Experience. (Karachi: United Kingdom: The Islamic Foundation, 1981), 137.

5 Arif Hoetoro. Ekonomi Islam Perspektif Historis dan Metodologis. (Malang: Empatdua, 2017), 64.

55 | Ulumunâ: Jurnal Studi Keislaman
} 
Baitul Maal pada masa Rasulullah SAW dan Khulafaurasyidin yang ditinjau dari perspektif sejarah kemudian dikaitkan dengan analisa konteks pada masa Negara Indonesia merupakan hal yang penting dan menarik untuk dikaji lebih jauh berdasarkan hasil temuan konsep dan hasil riset sebelumnya. Hal ini akan memberikan pemahaman pentingnya peran lembaga keuangan publik Islam yang mengatur segala harta umat untuk terwujudnya kesejahteraan ummat.

Pendekatan kualitatif digunakan dalam penelitian ini dalam bentuk katakata, skema, dan gambar. ${ }^{6}$ Penelitian ini akan menganalisis perkembangan praktik Baitul Maal pada masa Rasulullah SAW dan Khulafaurasyidin serta perkembangan eksistensi Baitul Maal saat ini di Indonesia. Adapun teknik pengumpulan data melalui studi pustaka yang dilaksanakan dengan menggunakan studi kepustakaan yang sesuai dengan topik penelitian.

\section{Perkembangan Baitul Maal Pada Masa Daulah Islamiyah}

Baitul Maal berasal dari Bahasa Arab yakni “bait” artinya rumah, dan "almal" yang artinya harta. Baitul Maal dalam arti etimologis yaitu rumah untuk mengumpulkan atau menyimpan harta. Adapun secara terminologis menurut Abdul Qadim Zallum (1983) dalam kitabnya Al-Amwaal Fi Daulah Al Khilafah, Baitul Maal adalah suatu lembaga atau pihak yang memiliki tugas khusus menangani segala harta ummat, baik berupa pendapatan maupun pengeluaran negara. Sumber utama pendapatan negara pada awal perkembangan Islam adalah khums, zakat, kharaj dan jizyah yang ketentuannya didasarkan pada ketentuan Syariah. Pada saat itu yang menjadi tempat pengumpulan dan pembagian harta tersebut adalah masjid yang didirikan oleh Rasulullah SAW setelah hijrah. Perkembangan selanjutnya pada masa awal pemerintahan Rasulullah SAW Baitul Maal masih belum bersifat kelembagaan. Kemudian perkembangan Baitul Maal pada saat itu menjadi Kantor Perbendaharaan Negara yang baru dibentuk pada pemerintahan Khalifah Umar bin Khattab (643-644). ${ }^{7}$

Pada masa awal pemerintahan Rasulullah SAW Baitul Maal terletak di Masjid Nabawi yang saat itu digunakan sebagai kantor pusat negara sekaligus

\footnotetext{
${ }^{6}$ Sugiyono. Metode Penelitian Kuantitatif Kualitatif dan R\&D. (Bandung: Alfabeta, 2013), 79.

${ }^{7}$ Karnaen, A. P. \& Anis, B. Jejak Rekam Ekonomi Islam Refleksi Peristiwa Ekonomi dan Pemikiran Para Ahli Sepanjang Sejarah Kekhalifahan. (Jakarta: Cicero Publishing, 2008), 35.
} 
sebagai tempat tinggal Rasulullah SAW. Adapun binatang-binatang yang termasuk harta perbendaharaan negara ditempatkan di padang terbuka sesuai dengan alamnya. Pendistribusian harta dilakukan dalam jangka waktu yang singkat untuk didistribusikan kepada masyarakat hingga tidak tersisa sedikitpun. Kemudian perkembangan berikutnya Baitul Maalmemiliki peranan penting dalam bidang keuangan dan administrasi negara terutama pada masa pemerintahan Khilafah ar-Rasyidin. ${ }^{8}$

Pengalokasian dana Baitul Maal pada masa Nabi Muhammad SAW digunakan untuk dakwah penyebaran Islam, pendidikan dan kebudayaan, pengembangan ilmu pengetahuan, pengembangan infrastruktur, pembangunan armada perang dan keamanan, serta penyediaan layanan kesejahteraan sosial. ${ }^{9}$ Baitul Maal pada masa Rasulullaah SAW berfungsi sebagai lembaga pengelolaan keuangan negara yang terkait pelaksanaan kebijakan yang secara tidak langsung memberikan dampak terhadap perekonomian makro. Salah satu ciri kebijakan fiskal di Baitul Maal pada masa Rasulullah SAW yaitu menerapkan balance budget, artinya sangat jarang terjadi anggaran defisit walaupun tercatat hanya sekali terjadi ketika jatuhnya Kota Makkah. Akibat dari hal ini, maka utang dari defisit anggaran ini dibayarkan kurang dari satu tahun yakni setelah berakhirnya perang Hunayn. ${ }^{10}$

Pengelolaan Baitul Maal pada zaman Khalifah Abu Bakar Ash Shidiq (1113 H/632-634 M) masih berlangsung sama pada masa Rasulullah SAW, namun saat kekhilafahannya di tahun kedua $(12 \mathrm{H} / 633 \mathrm{M})$, Abu Bakar membangun embrio Baitul Maal yang tidak hanya sebagai pihak (al-jïhat) yang mengelola harta umat, namun berfungsi sebagai tempat (al-makan) untuk menyimpan harta negara. Pada saat itu Abu Bakar menyediakan rumahnya sebagai tempat (kamar) untuk menyimpan harta yang masuk dari berbagai daerah. Hal ini berlangsung sampai Khalifah Abu Bakar wafat pada 13 H/634 M. ${ }^{11}$ Masyarakat mengenal sosok Abu Bakar sebagai khalifah yang sangat wara' atau hati-hati dalam masalah harta. Harta Baitul Maal selama masa kekhalifahan

\footnotetext{
8 Adiwarman, A. A. Sejarah Pemikiran Ekonomi Islam. (Jakarta: Raja Grafindo Persada, 2014), 37.

${ }^{9}$ Euis, A. Sejarah Pemikiran Ekonomi Islam dari Masa Klasik bingsa Kontemporer. (Depok: Gramata Publishing, 2005), 79.

10 Adiwarman, A. A. Ekonomi Makro Islam. (Jakarta: Raja Grafindo Persada,2017), 247.

11 Nurul, H. \& dkk. Kenangan Publik Islam Pendekatan Teoritis dan Sejarah. (Jakarta: Kencana, 2012), 275.
}

$57 \mid$ Ulamunâ: Jurnal Studi Keislaman 
Abu Bakar langsung didistribusikan kepada seluruh kaum Muslimin, sehingga harta tidak menumpuk di Baitul Maal. ${ }^{12}$ Pengelolaan harta Baitul Maal pada masa Abu Bakar menerapkan prinsip kesamarataan, artinya harta di Baitul Maal akan diberikan kepada semua sahabat Rasulullah SAW dengan jumlah yang sama. ${ }^{13}$

Selain itu, Khalifah Abu Bakar melakukan pengembangan pembangunan dan penanggung jawab Baitul Maal serta menerapkan konsep balance budget pada Baitul Maal, artinya seluruh harta pendapatan langsung didistribusikan tanpa disediakannya cadangan. ${ }^{14}$ Menurut catatan Ibnu Khaldun, Khalifah Umar pada tahun $(13 \mathrm{H} / 634 \mathrm{M})$ membangun lembaga Baitul Maal sebagai kantor bendahara negara serta membuat dokumen khusus tentang Baitul Maal yang berisi hal-hal yang berkaitan dengan pemasukan dan pembelanjaan kas negara. ${ }^{15}$ Orang pertama yang membuat dokumen negara dalam Islam yaitu Khalifah Umar. Pengelolaan Baitul Maal tidak terjadi perubahan ketika masa pemerintahan Abu Bakar, sedangkan ketika masa pemerintahan Umar yang pada saat itu terjadi berbagai ekspekdisi oleh kaum Muslimin, sehingga pendapatan meningkat yang diperoleh dari hasil pajak tanah yang ditaklukan, sehingga terdapat perubahan terhadap sistem administrasi pemerintahan Umar, kemudian Khalifah Umar memberi amanah kepada beberapa orang sebagai pengelola dan pencatat yang berasal dari Persia untuk bertugas mengatur serta mengawasi pembukuan di Baitul Maal. Adanya perubahan pengelolaan pada Baitul Maal oleh Khalifah Umar merupakan masukan dari Homozan yang merupakan seorang tahanan dari Persia. Kemudian Homozan masuk Islam dan tinggal di Madinah. Setelah itu Homozan menjelaskan tentang sistem administrasi yang dilakukan oleh Raja Sasanian kepada Khalifah Umar. ${ }^{16}$

${ }^{12 N u r u l, ~ H . ~ \& ~ d k k . ~ K e n a n g a n ~ P u b l i k ~ I s l a m ~ P e n d e k a t a n ~ T e o r i t i s ~ d a n ~ S e j a r a h . ~(J a k a r t a: ~}$

Kencana, 2012), 276

13 Adiwarman, A. A. Sejarah Pemikiran Ekonomi Islam. (Jakarta: Raja Grafindo Persada, 2014), 57.

${ }_{14}$ Nurul, H. \& dkk. Ekonomi Makro Islam Pendekatan Teoritis. (Jakarta: Kencana, 2014), 163.

15 Karnaen, A. P. \& Anis, B. Jejak Rekam Ekonomi Islam Refleksi Peristiwa Ekonomi dan Pemikiran Para Abli Sepanjang Sejarah Kekhalifahan. (Jakarta: Cicero Publishing, 2008), 73 74.

16 Adiwarman, A. A. Sejarah Pemikiran Ekonomi Islam. (Jakarta: Raja Grafindo Persada, 2014), 100.

Vol.6 No. 1 Juni $2020 \mid 58$ 
Latar belakang pendirian lembaga instritusi Baitul Maal diawali dengan kedatangan seorang Gubernur Bahrain yaitu Abu Hurairah. Adanya kedatangan Abu Hurairah saat itu membawa harta hasil pengumpulan alkharaj pada tahun $16 \mathrm{H}$ sebesar 500 ribu dirham. Perkembangan selanjutnya wilayah kekuasaan Islam yang semakin meluas dalam masa Khalifah Umar dan mengalami peningkatan pendapatan negara yang signifik. ${ }^{17}$ Kemudian Khalifah Umar bin Khattab dengan para pemuka sahabat melakukan musyawarah dalam mengambil kebijakan agar menghabiskan harta Baitul Maal sekaligus, namun pengeluaran Baitul Maal akan dilakukan secara bertahap yang disesuaikan dengan kebutuhan negara, sehingga harta Baitul Maal terdapat dana cadangan. Dana cadangan Baitul Maal tersebut digunakan untuk memenuhi kebutuhan yang sifatnya darurat, pembayaran gaji tantara serta kebutuhan ummat lainnya. ${ }^{18}$

Pembangunan lembaga Baitul Maal pertama yakni ketika $16 \mathrm{H}$ yang berpusat di Madinah, selanjutnya diikuti oleh pembangunan cabang-cabang Baitul Maal di masingmasing ibukota provinsi. Abdullah bin Irqam ditunjuk oleh Khalifah Umar untuk menjadi bendahara negara dengan Abdurrahman bin Ubaid Al-Qari dan Muayqab sebagai wakilnya yang bertugas dalam mengelola Baitul Maal. Sejak saat itulah terjadi peningkatan pendapatan Baitul Maal setelah penaklukan Syiria, Sawad (Irak) dan Mesir. Peningkatan pendapatan tersebut diperoleh dari Sawad jenis kharaj sebesar seratus juta dinar sedangkan dua juta dinar dari Mesir. ${ }^{19}$ Kebijakan yang telah dilakukan pada pemerintahan Khalifah Umar terkait Baitul Maal adalah reorganisasi yakni menjadikan fungsi Baitul Maal sebagai institusi negara resmi yang dikenal sebagai al-divan. Fungsi al-divan ini sebagai kantor yang ditujukan untuk membayar tunjangan angkatan perang dan pensiun serta tunjangan lainnya.

${ }^{17}$ Adiwarman, A. A. Sejarah Pemikiran Ekonomi Islam. (Jakarta: Raja Grafindo Persada, 2014), 59-60.

18 Rozalinda. Ekonomi Islam Teori dan Aplikasinya pada aktivitas Ekonomi. (Depok: PT Raja Grafindo Persada, 2017), 56.

19 Adiwarman, A. A. Sejarah Pemikiran Ekonomi Islam. (Jakarta: Raja Grafindo Persada, 2014), 60.

59 | Ulamunâ : Jurnal Studi Keislaman 
Oleh karena itu, negara memiliki kewajiban dalam penyediaan serta pemenuhan kebutuhan dasar bagi masyarakatnya. ${ }^{20}$

Kebijakan fiskal dan anggaran belanja dalam prinsip Islam harus didasarkan atas distribusi kekayaan berimbang yang memperhatikan aspek material dan spiritual. ${ }^{21} \mathrm{Di}$ samping itu adanya pembentukan beberapa departemen oleh Khalifah Umar yang dianggap perlu dalam mendistribusian harta di Baitul Maal dan pada tahun $20 \mathrm{H}$ departemen tersebut mulai dipraktekkan untuk pertama kalinya. ${ }^{22}$

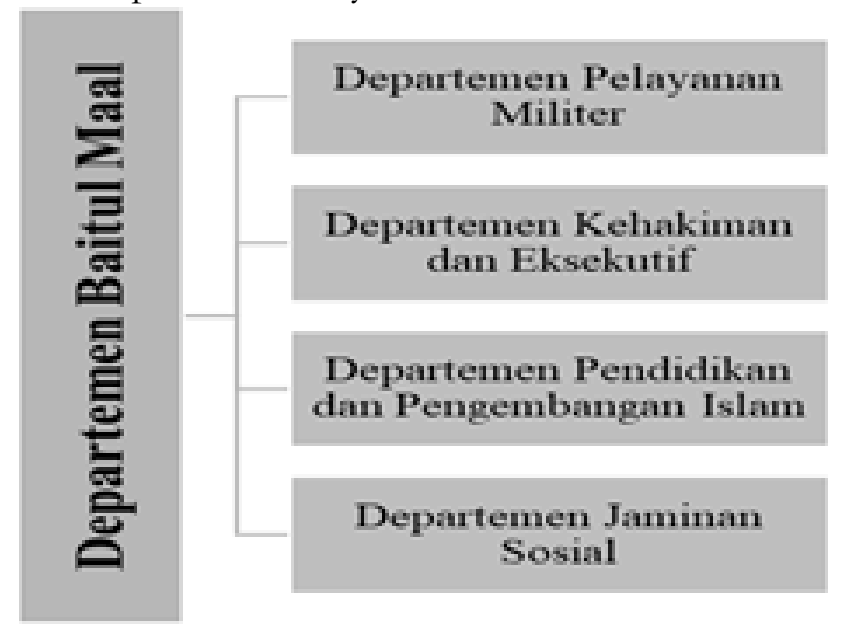

Gambar 1.

\section{Pembagian Departemen Baitul Maal}

Berdasarkan Gambar 1. menunjukkan adanya perubahan pengelolaan lembaga Baitul Maal sekaligus merealisasikan salah satu fungsi negara Islam yaitu adanya jaminan sosial. Hal ini merupakan tujuan penting dalam sistem ekonomi Islam yakni tersedianya kebutuhan dasar bagi seluruh masyarakat. ${ }^{23}$ Pemenuhan kebutuhan dasar minum bagi masyarakat merupakan tanggung jawab dan peran negara.

${ }^{20}$ Nurul, H. \& dkk. Ekonomi Makro Islam Pendekatan Teoritis. (Jakarta: Kencana, 2008), 164.

${ }^{21}$ Eko Suprayitno. Ekonomi Islam Pendekatan Ekonomi Makro Islam dan Konvensional. (Yogyakarta: Graha Ilmu, 2005), 160.

${ }^{22}$ Euis, A. Sejarah Pemikiran Ekonomi Islam dari Masa Klasik hingga Kontemporer. (Depok: Gramata Publishing, 2005), 91.

${ }^{23}$ M. Sharif Chaudhry. Sistem Ekonomi Islam: Prinsip Dasar. (Jakarta: Kencana, 2012), 33. Vol.6 No. 1 Juni $2020 \mid 60$ 
Perkembangan Baitul Maal pada tahun 23-35 H/644-656 M zaman Khalifah Utsman bin Affan memiliki kebijakan antara lain kebijakan Khalifah Umar tidak diterapkan lagi. Selama ini faktor-faktor yang dikuasai oleh negara akan menjadi miliki individu, akibatnya banyak tuan-tuan tanah, sehingga akan merubah sistem sumber pendapatan negara. Prinsip persamaan dalam memenuhi kebutuhan pokok masyarakat dilakukan oleh Khalifah Ustman. Khalifah Ustman memiliki prinsip persamaan dalam memenuhi kebutuhan pokok masyarakat, Khalifah Ustman akan memberikan bantuan yang berbeda pada tingkat yang lebih tinggi. ${ }^{24}$ Dengan demikian, prinsip keutamaan diterapkan pada masa Khalifah Ustman dan Khalifah Umar.

Pada masa Khalifah Ali, perkembangan Baitul Maal pada tahun 35-40 H/656-661 M yang pindah ke ibukota negara dari Madinah ke Kufah, akibatnya pusat Baitul Maal pindah ke Kufah. Perpindahan Baitul Maal ini membawa keuntungan setelah penaklukan di daerah Irak, Syiria, Iran dan wilayah lainnya. Secara geografis letak Baitul Maal sangat strategis karena letaknya di ibu kota negara. Selanjutnya terjalin komunikasi berjalan lancer antara Kufah dengan pusat pemerintahan provinsi, sehingga setiap provinsi juga didirikan Baitul Maal. ${ }^{25}$ Selain itu, sistem pengelolan administrasi Baitul Maal menjadi lebih baik di tingkat pusat dan daerah. Hal ini mendorong pendapatan Baitul Maal yang surplus dengan adanya kerjasama antara keduanya. Pendistribusian harta pada masa Khalifah Ali menerapkan prinsip pemerataan. $^{26}$

Di samping itu, seluruh pendapatan negara yang disimpan dalam Baitul Maal menurut Khalifah Ali harus segera diberikan kepada kaum Muslimin tanpa adanya sisa atau dana cadangan. Pendistribusian harta pada masa Khalifah Ali dilakukan Hari Kamis, artinya Khalifah Ali hanya melakukan pendistribusian harta sekali saja dalam satu pekan. Kebijakan yang diterapkan dalam pengelolaan Baitul Maal oleh Khalifah Ali secara umum memiliki

\footnotetext{
${ }^{24}$ Euis, A. Sejarah Pemikiran Ekonomi Islam dari Masa Klasik hingga Kontemporer. (Depok: Gramata Publishing, 2005), 96.

25 Adiwarman, A. A. Sejarah Pemikiran Ekonomi Islam. (Jakarta: Raja Grafindo Persada, 2014), 100.

26 Euis, A. Sejarah Pemikiran Ekonomi Islam dari Masa Klasik hingga Kontemporer. (Depok: Gramata Publishing, 2005), 97.

$61 \mid$ Ulumunâ: Jurnal Studi Keislaman
} 
persamaan dengan masa Rasulullah SAW dan Abu Bakar, namun berbeda dengan kebijakan Umar yang menyediakan dana cadangan dari harta Baitul Maal. Khalifah Ali lebih memperhatikan untuk menjamin bagian dari masingmaisng setiap orang dari dana Baitul Maal. Gubernur diperintahkan oleh Khalifah Ali untuk mendistribusikan harta dari dana Baitul Maal dengan tepat sasaran kepada kelompok-kelompok yang telah disebutkan oleh Allah SWT. ${ }^{27}$

Berdasarkan pemaparan perkembangan Baitul Maal pada masa Rasulullah SAW dan Khulafaurasyidin selalu mengalami perkembangan dan perbaikan dari segi kelembagaan, tempat, administrasi atau pencatatan, pembangunan Baitul Maal lokal di setiap provinsi, kebijakan fiskal dalam pendistribusian harta Baitul Maal serta kebijakan lainnya. Oleh karena itu maka Baitul Maal memiliki peran dan fungsi yang penting sebagai lembaga keuangan publik Islam pada masanya serta dapat dilihat petunjuk tentang cara mengelola Baitul Maal dalam sektor pemenuhan kebutuhan publik.

\section{Perkembangan Eksistensi Baitul Maal di Indonesia}

Berdasarkan hasil temuan konsep Baitul Maal yang ditinjau dari perspektif sejarah pada masa Nabi Muhammad SAW dan para Khulafaurasyidin dapat diketahui bahwa Baitul Maal merupakan institusi lembaga negara sebagai tempat dan pengelolaan seluruh harta kekayaan negara yang bersumber dari dana umat untuk tercapainya kesejahteraan masyarakat. Di sisi lain Baitul Maal saat ini dalam konteks negara Indonesia dengan masa Daulah Islamiyah tentu akan memiliki perbedaan. Berdasarkan UUD 1945 Pasal 1, Indonesia adalah Negara Kesatuan Republik Indonesia (NKRI) dan dipimpin oleh seorang Presiden sebagai kepala pemerintahan atau negara yang diangkat melalui sistem demokrasi. Presiden akan dibantu oleh Menteri-menteri negara sesuai dengan Peraturan Presiden Nomor 47 Tahun 2009 tentang Pembentukan dan Organisasi Kementerian Negara dan untuk menjamin terselenggaranya tugas pemerintahan yang terdapat dalam Pasal 17. Oleh karena itu, maka pengaturan keuangan negara dan sektor publik akan berbeda dengan masa Daulah Islamiyah walaupun saat ini Indonesia memiliki populasi mayoritas Muslim terbesar di dunia yakni sebesar 87 persen terhadap total penduduk Indonesia.

27 Adiwarman, A. A. Sejarab Pemikiran Ekonomi Islam. (Jakarta: Raja Grafindo Persada, 2014), 103.

Vol.6 No. 1 Juni 2020 |62 
Baitul Maal dalam konteks Indonesia sebagai negara mayoritas Muslim dan berdasarkan sistem pemerintahan demokrasi, maka peran dan fungsinya mengalami perubahan dan pengaturan pengelolaannya berbeda dengan konsep Baitul Maal di masa Daulah Islamiyah. Saat ini Baitul Maal (rumah harta) di Indonesia termasuk ke dalam Industri Keuangan Non-Bank (IKNB) atau Lembaga Keuangan Mikro Syariah (LKMS) yang berfungsi hanya menerima dan mengelola titipan dana zakat, infak, dan sedekah saja serta mengoptimalkan pendistribusiannya sesuai dengan ketentuan Syariah dan peraturan yang berlaku. Di samping itu biasanya terdapat fungsi pengembangan harta dengan orientasi profit melalui Baitul Tamwil (rumah pengembangan harta) yang terdapat skema kerjasama kegiatan usaha bisnis berdasarkan akad-akad Syariah.

Salah satu tonggak penting pendirian Baitul Mal Wa Tamwiil (BMT) di Indonesia yaitu ketika didirikannya Pusat Inkubasi Bisnis Usaha Kecil (Pinbuk) tahun 1995 oleh Ketua Umum MUI, Ketua Umum ICMI dan Direktur Utama bank Muamalat Indonesia yang merupakan salah satu Lembaga paling aktif mendorong pendirian BMT yang dirancang sebagai Lembaga keuangan mikro Syariah. Kegiatan BMT fokus kepada masyarakat kelas bawah melalui pemberian akses pembiayaan Syariah. ${ }^{28}$ Selain itu, pengembangan BMT sebagai model pendukung brancbless banking di Indonesia. ${ }^{29}$ Berikut ini gambaran secara umum operasional BMT di Indonesia pada Gambar 3 yaitu:

\footnotetext{
${ }^{28}$ Darsono, dkk. Peta Kenangan Mikro Syariah Indonesia. (Jakarta: Tazkia Publishing, Bank Indonesia, 2018), 319.

29 Bedjo, Santoso. \& Khaliq, A, "Islamic Microfinance Branchless Baning Model ini Indonesia”, Intellectual Discourse, Special Issue, 2016, 409-433.

$63 \mid$ 'Ulumunâ: Jurnal Studi Keislaman
} 


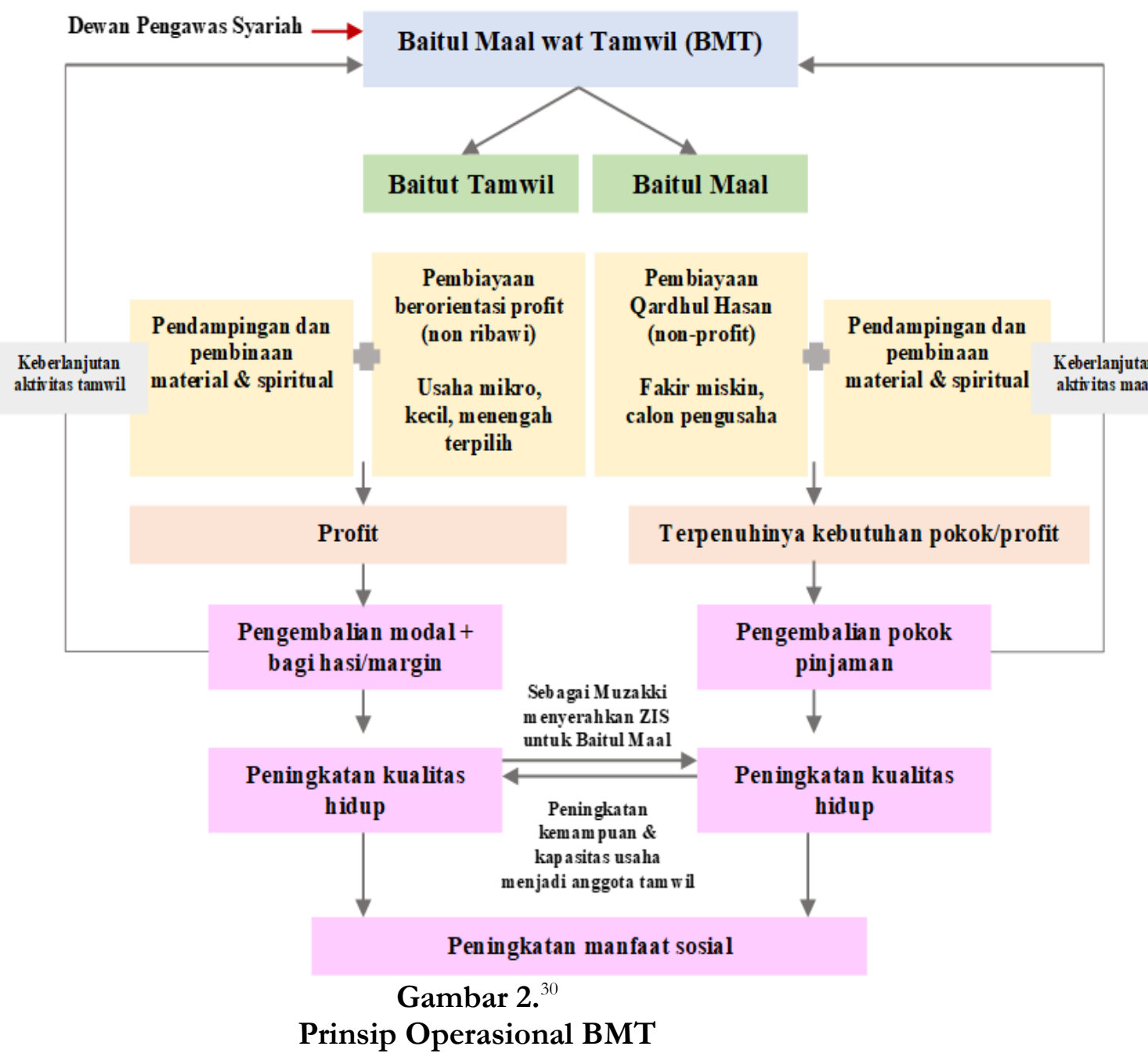

Secara umum ruang lingkup kegiatan BMT pada Gambar 2. yaitu pengelolaan dan pendistribusian dana sosial filantropi seperti zakat, infaq, sedekah dan wakaf. Adapun dalam kegiatan yang berbasis profit dilakukan melalui sistem bagi hasil seperti mudharabah, musyarakah, margin dalam jual beli (murabahah, bai assalam, bai istishna) dan sistem sewa (ijarah). Kelembagaan BMT

30 Darsono, Op. Cit, hlm. 322. 
di Indonesia berada di bawah pengawasan Otoritas Jasa Keuangan (OJK) dan saat ini sebagian besar BMT berbadan hukum koperasi. Oleh karena itu, BMT berada di bawah Kementerian Koperasi dan UKM. Adanya dua aktivitas dalam BMT yakni sosial dan komersial, maka diperlukan pemisahan administrasi, pencatatan, pelaporan yang diperlukan untuk meningkatkan kepercayaan publik. Selain itu peranan BMT di Indonesia memiliki peluang pemberdayaan terhadap masyarakat kelas bawah. sebagai Lembaga Keuangan Mikro Syariah

Berdasarkan hasil telaah konsep dan praktik Baitul Maal pada masa Rasulullah SAW dan Khulafaurasyidin kemudian dianalisis dalam konteks perkembangan eksistensi Baitul Maal di Indonesia yaitu pada Tabel 1.:

Tabel 1.

\section{Perbedaan Praktik Baitul Maal Pada Masa Daulah Islamiyah dan di} dalam Konteks di Indonesia

\begin{tabular}{|c|c|c|}
\hline $\begin{array}{l}\text { Perbedaan dari } \\
\text { Segi }\end{array}$ & $\begin{array}{l}\text { Praktik Baitul Maal Masa Daulah } \\
\text { Islamiyah }\end{array}$ & $\begin{array}{c}\text { Praktik Baitul Maal di } \\
\text { Indonesia }\end{array}$ \\
\hline Definisi & $\begin{array}{l}\text { Lembaga atau pihak yang memiliki } \\
\text { tugas khusus menangani segala harta } \\
\text { ummat atau kekayaan negara baik } \\
\text { berupa pendapatan maupun } \\
\text { pengeluaran negara. }\end{array}$ & $\begin{array}{l}\text { Rumah harta yang menerima } \\
\text { titipan dana zakat, infaq, sedekah } \\
\text { serta mengoptimalkan distribusinya } \\
\text { sesuai dengan peraturan dan } \\
\text { amanatnya. }\end{array}$ \\
\hline Kelembagaan & $\begin{array}{l}\text { Nama Institusi Baitul Maal sebagai } \\
\text { pihak (aljihat), badan atau lembaga } \\
\text { yang menangani harta negara. Selain } \\
\text { itu terdapat Baitul Maal pusat di } \\
\text { Madinah dan Baitul Maal lokal yang } \\
\text { didirikan diberbagai distrik dan } \\
\text { provinsi seiring dengan perluasan } \\
\text { daerah taklukan oleh Islam. }\end{array}$ & $\begin{array}{l}\text { Nama institusi Baitul Maal sebagai } \\
\text { bagian dari Baitul Maal Wat Tamwil } \\
\text { (BMT) yang merupakan Lembaga } \\
\text { Keuangan Mikro Syariah (LKMS) } \\
\text { dengan paying hukum Koperasi } \\
\text { Jasa Keuangan syariah (KJKS) dan } \\
\text { termasuk ke dalam Industri } \\
\text { Keuangan Non-Bank (IKNB) di } \\
\text { bawah UU No. } 1 \text { tahun 2013. }\end{array}$ \\
\hline Peran dan fungsi & $\begin{array}{l}\text { a. Baitul Maal berperan penting } \\
\text { dalam bidang keuangan, } \\
\text { administrasi negara serta } \\
\text { penyediaan kebutuhan publik } \\
\text { terutama pada masa pemerintahan } \\
\text { al-Khulafa al-Rasyidin. }\end{array}$ & $\begin{array}{l}\text { Baitul Maal berperan dalam } \\
\text { membantu fungsi Lembaga } \\
\text { filantropi dalam pengumpulan dan } \\
\text { pemanfaatan dana sosial seperti } \\
\text { zakat, infaq dan sedekah bagi } \\
\text { kesejahteraan masyarakat. Oleh } \\
\text { karena itu Baitul Maal yang }\end{array}$ \\
\hline
\end{tabular}




\begin{tabular}{|c|c|c|}
\hline & $\begin{array}{l}\text { b. Baitul Maal berfungsi dalam hal } \\
\text { pengumpulan dan pendistribusian } \\
\text { harta negara kepada masyarakat } \\
\text { serta berfungsi secara tidak } \\
\text { langsung sebagai pelaksana } \\
\text { kebijakan fiskal negara Islam dan } \\
\text { Khalifah. }\end{array}$ & $\begin{array}{l}\text { berfungsi sebagai bendahara negara } \\
\text { pada konteks saat ini dalam } \\
\text { perekonomian modern disebut } \\
\text { Departemen Keuangan }\end{array}$ \\
\hline $\begin{array}{l}\text { Sumber } \\
\text { Pendapatan }\end{array}$ & $\begin{array}{l}\text { Pendapatan Baitul Maal antara lain } \\
\text { kharaj, zakat, khums, jizyah, } \\
\text { ghanimah dan pemasukan lainnya } \\
\text { seperti kafarat. }\end{array}$ & $\begin{array}{l}\text { Pemasukan dana Baitul Maal antara } \\
\text { lain zakat, infaq, sedekah dana dana } \\
\text { sosial keagamaan lainnya. }\end{array}$ \\
\hline $\begin{array}{l}\text { Jenis } \\
\text { Pengeluaran }\end{array}$ & $\begin{array}{l}\text { Jenis pengeluaran Baitul Maal antara } \\
\text { lain penyebaran Islam, gerakan } \\
\text { pendidikan dan kebudayaan, } \\
\text { pengembangan ilmu pengetahuan, } \\
\text { pembangunan infrastruktur, } \\
\text { pembangunan armada perang dan } \\
\text { keamanan, penyediaan layanan } \\
\text { kesejahteraan sosial }\end{array}$ & $\begin{array}{l}\text { Jenis pengeluaran Baitul Maal } \\
\text { antara lain sesuai dengan amanat } \\
\text { peraturan UU No. } 23 \text { tentang } \\
\text { Pengelolaan Zakat. Artinya jenis } \\
\text { pengeluaran Baitul Maal di } \\
\text { Indonesia hanya fokus pada } \\
\text { penyediaan layanan kesejahteraan } \\
\text { sosial melalui penyaluran atau } \\
\text { pendayagunaan zakat serta tidak } \\
\text { bertanggung jawab terhadap } \\
\text { penyediaan kebutuhan publik } \\
\text { seperti pertahanan, infrastruktur } \\
\text { pembayaran gaji pegawaai negeri } \\
\text { dan lainnya. }\end{array}$ \\
\hline
\end{tabular}

Sumber: Hasil analisis penulis (2019)

Berdasarkan Tabel 1. menunjukkan bahwa terdapat beberapa poin perbedaan praktik perkembangan Baitul Maal pada masa Daulah Islamiyah dan eksistensinya di Indonesia saat ini. Perbedaan pertama ditinjau dari sisi konsep Baitul Maal pada masa Daulah Islamiyah merupakan lembaga keuangan negara yang berkaitan dengan pengelolaan pendapatan dan belanja negara, sedangkan saat ini di Indonesia berada dibawah Kementerian Keuangan Republik Indonesia. Pengelolaan keuangan negara saat ini tentu saja memiliki perbedaan dalam pengelolaan keuangan negara yang lebih kompleks, artinya tidak sesederhana pengelolaan ketika zaman dahulu. Hal ini dilihat berdasarkan perumusan APBN Indonesia yang harus memperhatikan pertimbangan Vol.6 No. 1 Juni 2020 | 66 
Dewan Perwakilan Daerah (DPR) RI. Selain itu pengelolaan anggaran pendapatan dan belanja negara tersebut harus menggunakan asumsi dasar ekonomi makro seperti tingkat pertumbuhan ekonomi, inflasi, nilai tukar, suku bunga, harga minyak, lifting minyak dan lifting gas.

Sejarah pengelolaan keuangan negara di Indonesia sudah ada sejak masa lampau. Setiap pemerintahan, mulai zaman kerajaan sampai sekarang memiliki pengelola keuangan untuk memastikan terlaksananya pembangunan dalam pemerintahannya. Pembangunan ekonomi akan berjalan lancar jika disertai dengan administrasi yang baik dalam pengelolaan keuangan negara. Pengelolaan keuangan tersebut dilakukan atas dana yang dihimpun dari masyarakat, antara lain berupa upeti, pajak, bea dan cukai, dan lain-lain. Kementerian Keuangan sebagai bagian dari suatu pemerintahan yang merupakan instansi pemerintah yang memiliki peranan vital dalam suatu negara. Peranan vital Kementerian Keuangan adalah mengelola keuangan negara dan membantu pimpinan negara di bidang keuangan dan kekayaan negara. Oleh karena itu, Kementerian Keuangan dikatakan sebagai penjaga keuangan negara (Nagara Dana Rakca). ${ }^{31}$

Taqiyuddin an-Nabani berpendapat bahwa fungsi Baitul Maal pada dasarnya sebagai tempat pengumpulan dan penyaluran anggaran negara lintas nasional akan tetapi pada konteks saat ini bahwa Baitul Maal berfungsi sebagai penyalur dan penggerak dana sosial lintas mikro. Selain itu konsep dari Taqiyuddin an-Nabani ini memang menjadi pertimbangan untuk diteapkan mengingat Indonesia bukan negara Islam sehingga tidak bisa menerapkan sistem Islam secara sempurna seperti halnya bahwa Baitul Maal dapat menangani pengelolaan keuangan negara secara nasional. ${ }^{32}$

Di sisi lain perkembangan konsep Baitul Maal di Indonesia saat ini yaitu sebagai lembaga penghimpun dana sosial keagamaan (Rumah Harta) seperti zakat, infaq dan sedekah serta menyalurkannya sesuai dengan Al-Qur'an dan Hadist. Kedua, perbedaan konsep Baitul Maal ini tentu akan memiliki perbedaan

\footnotetext{
${ }^{31}$ Kementerian Keuangan. (2019). Sejarah Pengelolaan Keuangan Negara. Retrieved from https://www.kemenkeu.go.id/profil/sejarah/sejarah pengelolaan-keuangan/. Diakses 12 Maret 2019.

32 Diyaa Aaisyah S.P.A, Muhsin Hariyanto, Roy. Analysis of Islamic Public Finance Management in Baitul Mal in Perspective of Life is Place of Worshipdomain In Spiritual Management (A Study Of Taqiyuddin AnNabhani's Thought). International Journal Of Scientific \& Technology Research, Volume 7, Issue 12, December 2018

$67 \mid$ Ulümnâ: Jurnal Studi Keislaman
} 
dari kedua yaitu kelembagaan Baitul Maal, di mana Baitul Maal pada masa Daulah Islamiyah sebagai pihak (aljihat), badan atau lembaga yang menangani harta negara. Selain itu terdapat Baitul Maal pusat di Madinah dan Baitul Maal lokal yang didirikan diberbagai distrik dan provinsi seiring dengan perluasan daerah taklukan oleh Islam. Adapun Baitul Maal di Indonesia saat ini sebagai bagian dari Baitul Maal Wat Tamwil (BMT) yang merupakan Lembaga Keuangan Mikro Syariah (LKMS) dengan paying hukum Koperasi Jasa Keuangan syariah (KJKS) dan termasuk ke dalam Industri Keuangan NonBank (IKNB) di bawah UU No. 1 tahun 2013.

Ketiga, berdasarkan peran dan fungsi Baitul Maal pada masa Daulah Islamiyah memiliki peran penting dalam bidang keuangan, administrasi negara serta penyediaan kebutuhan publik terutama pada masa pemerintahan alKhulafa al-Rasyidin. Selain itu Baitul Maal berfungsi dalam hal pengumpulan dan pendistribusian harta negara kepada masyarakat serta berfungsi secara tidak langsung sebagai pelaksana kebijakan fiskal negara Islam dan Khalifah. Adapun peran dan fungsi Baitul Maal di Indonesia saat ini berperan dalam membantu fungsi Lembaga filantropi dalam pengumpulan dan pemanfaatan dana sosial seperti zakat, infaq dan sedekah bagi kesejahteraan masyarakat. Oleh karena itu Baitul Maal yang berfungsi sebagai bendahara negara pada konteks saat ini dalam perekonomian modern disebut Departemen Keuangan.

Keempat, di samping itu apabila ditinjau dari sumber-sumber penerimaan negara pada Baitul Maal pada masa Daulah Islamiyah dengan pendapatan negara Indonesia saat ini berbeda antara lain adanya peranan instrumen filantropi atau dana sosial seperti zakat tidak menjadi sumber utama pendapatan negara, namun dikelola melalui Badan Amil Zakat Nasional (BAZNAS) sebagai lembaga zakat pemerintah independen non-struktural yang bertugas dalam penghimpunan, pendistribusian, dan pendayagunaan zakat serta dan dibantu oleh Lembaga Amil Zakat (LAZ) sebagai lembaga zakat swasta yang dikelola oleh masyarakat sipil yang melayani kepentingan publik dalam penghimpunan dan penyaluran dana umat berdasarkan UU No. 23 Tahun 2011. Adapun sumber utama negara Indonesia adalah pajak yang berkontribusi besar terhadap pendapatan negara yakni pada tahun 2019 sebesar $82,5 \%$ dan sisanya dari penerimaan negara bukan pajak dan hibah. ${ }^{33}$

\footnotetext{
${ }^{33}$ Kementerian Keuangan. (2019). Publikasi Laporan Realisasi APBN 2019. Retrieved from https://www.kemenkeu.go.id/informasi-publik/realisasi-apbn/. Diakses 12 Maret 2019.
} 
Kelima, berdasarkan sisi jenis pengeluaran Baitul Maal pada masa Daulah Islamiyah bertugas untuk mendistribusikan harta negara dalam rangka penyediaan kebutuhan publik atau kebutuhan dasar bagi masyarakat antara lain penyebaran Islam, gerakan pendidikan dan kebudayaan, pengembangan ilmu pengetahuan, pembangunan infrastruktur, pembangunan armada perang dan keamanan, penyediaan layanan kesejahteraan sosial. Adapun jenis pengeluaran Baitul Maal di Indonesia saat ini antara lain sesuai dengan amanat peraturan UU No. 23 tentang Pengelolaan Zakat. Artinya jenis pengeluaran Baitul Maal di Indonesia hanya fokus pada penyediaan layanan kesejahteraan sosial melalui penyaluran atau pendayagunaan zakat serta tidak bertanggung jawab terhadap penyediaan kebutuhan publik seperti pertahanan, infrastruktur pembayaran gaji pegawaai negeri dan lainnya, namun tetap berperan dalam membantu pemenuhan kebutuhan negara dalam meningkatkan kesejahteraan masyarakat.

Berdasarkan temuan konsep Baitul Maal pada masa Daulah Islamiyah yang berfungsi sebagai tempat pengumpulan dana atau pusat pengumpulan kekayaan negara Islam yang digunakan untuk pengeluaran tertentu. Adapun pada awal perkembangan Islam, sumber utama pendapatan negara adalah khums, zakat, kharaj, dan jizyah dimana jumlah, jangka waktu serta penggunaannya didasarkan pada Al-Qur'an dan Hadist. Dengan demikian, berdasarkan uraian sebelumnya dapat disimpulkan bahwa konteks Baitul Maal pada masa Daulah Islamiyah dengan negara Indonesia saat ini berbeda. Hal ini dilatarbelakangi oleh bentuk negara atau sistem pemerintahan negara, sehingga fungsi Baitul Maal berbeda yakni tidak lagi sebagai pusat pengelolaan pendapatan dan belanja negara namun sebagai Lembaga Keuangan Mikro Syariah yang di samping dapat menerima titipan zakat, infak, dan sedekah namun terdapat fungsi lainnya dalam pengembangan harta (Baitul Tamwil).

\section{Kesimpulan}

Berdasarkan pembahasan dalam paper ini yaitu pertama, perkembangan Baitul Maal pada masa Rasulullah SAW dan Khulafaurasyidin selalu mengalami perkembangan dan perbaikan dari segi kelembagaan, tempat, administrasi atau pencatatan, pembangunan Baitul Maal lokal di setiap provinsi, kebijakan fiskal dalam pendistribusian harta Baitul Maal serta kebijakan lainnya. Kedua, sumber pendapatan utama Baitul Maal pada masa awal perkembangan Islam adalah 
khums, zakat, kharaj dan jizyah di mana jumlah, jangka waktu serta penggunaannya didasarkan pada Al-Qur'an dan Hadist. Selanjutnya terdapat perluasan sumber pendapatan Baitul Maal pada masa Khulafaurasyidin seperti khums, fa'i, rikaz, dan lainnya yang digunakan sebagai sumber alokasi pembelanjaan negara Islam.

Di sisi lain analisis keempat terkait pengeluaran dana Baitul Maal pada masa Daulah Islamiyah terhadap sektor layanan publik memiliki peranan aktif dalam ekonomi pada masa awal pemerintahan Islam. Kelima, analisis perkembangan eksistensi Baitul Maal pada masa Daulah Islamiyah dan di Indonesia saat ini memiliki perbedaan yang dapat ditinjau dari beberapa aspek antara lain konsep definisi, kelembagaan, peran dan fungsi, sumber pendapatan serta jenis pengeluaran Baitul Maal. Dengan demikian implikasi paper ini yaitu mampu memberikan pemahaman pentingnya peran lembaga keuangan publik Islam yang mengatur segala harta umat untuk terwujudnya kesejahteraan masyarakat.

\section{Daftar Pustaka}

Al-Qur'an dan Hadist.

Aaisyah, D., Hariyanto \& Royanti. (2018). Analysis of Islamic Public Finance Management in Baitul $\mathrm{Mal}$ in Perspective of Life is Place of Worshipdomain In Spiritual Management (A Study of Taqiyuddin AnNabhani's Thought). International Journal of Scientific \& Technology 7 (12), p. 1-4.

Amalia, Euis. (2005). Sejarah Pemikiran Ekonomi Islam dari Masa Klasik bingga Kontemporer. Depok: Gramata Publishing.

Arif, M. N. R. A. (2010). Teori Makroekonomi Islam Konsep Teori dan Analisis. Bandung: Alfabeta.

Chaudhry, Muhammad Sharif. (2012). Sistem Ekonomi Islam: Prinsip Dasar. Jakarta: Kencana.

Darsono, Syarifuddin, F., Sakti, A. \& Suryanti, E. T. (2018). Peta Kenangan Mikro Syariah Indonesia. Jakarta: Tazkia Pblishing, Bank Indonesia.

Hoetoro, Arif. (2017). Ekonomi Islam Perspektif Historis dan Metodologis. Malang: Empatdua.

Huda, Nurul., Idris, H. R., Nasution, M. E. dan Wliasih, R. (2014). Ekonomi Makro Islam Pendekatan Teoritis. Jakarta: Kencana.

Huda, Nurul., dkk. (2012). Kenangan Publik Islam Pendekatan Teoritis dan Sejarah. Jakarta: Kencana 
Huda, Nurul, dkk. (2008). Ekonomi Makro Islam Pendekatan Teoritis. Jakarta: Kencana.

Karim, A. A. (2014). Sejarah Pemikiran Ekonomi Islam. Jakarta: RajaGrafindo Persada.

Karim, A. A. (2017). Ekonomi Makro Islam. Jakarta: RajaGrafindo Persada.

Kementerian Keuangan. (2019). Realisasi Pengelolaan Pendapatan Kementerian Keuangan. Retrieved from https://www.kemenkeu.go.id/informasi publik/datapengelolaankeuangan-negara/realisasi-pendapatan-kementerian-keuangan/. Diakses 12 Maret 2019.

Kementerian Keuangan. (2019). Sejarah Pengelolaan Keuangan Negara. Retrieved from https://www.kemenkeu.go.id/profil/sejarah/sejarahpengelolaankeuangan/. Diakses 12 Maret 2019.

Perwataatmadja, K. A. \& Byarwati, A. (2008). Jejak Rekam Ekonomi Islam Refleksi Peristiwa Ekonomi dan Pemikiran Para Abli Sepanjang Sejarah Kekhalifahan. Jakarta: Cicero Publishing.

Rozalinda. (2017). Ekonomi Islam: Teori dan Aplikasi pada Aktivitas Ekonomi. Depok: PT Raja Grafindo Persada.

Santoso, B. \& Ahmad, K. (2016) "Islamic Microfinance Branchless Baning Model ini Indonesia”, Intellectual Discourse, Special Issue, Malaysia: International Islamic University of Malaysia, hlm. 409-433.

Soemitra, Andri. (2018). Bank dan Lembaga Keuangan Syariah. Jakarta: PrenadaMedia Grup.

Sugiyono. (2013). Metode Penelitian Kuantitatif Kualitatif dan R\&D. Bandung: Alfabeta.

Suprayitno, Eko. (2005). Ekonomi Islam Pendekatan Ekonomi Makro Islam dan Konvensional. Yogyakarta: Graha Ilmu.

Zaman, S. M. H. (1981). Economics Functions of an Islamic State The Early Experience. Karachi: United Kingdom: The Islamic Foundation.

Zallum, Abdul Qadim. (1983). Al Amwal Fi Daulah Al Khilafah. Cetakan I. Beirut: Darul 'Ilmi Lil Malayin. 